\title{
The Status of Authority in the Globalizing Economy Beyond the Public/Private Distinction
}

\author{
Hartmann, Eva; Kjær, Poul F.
}

Document Version

Accepted author manuscript

Published in:

Indiana Journal of Global Legal Studies

DOI:

10.2979/indjglolegstu.25.1.0003

Publication date:

2018

License

Unspecified

Citation for published version $(A P A)$ :

Hartmann, E., \& Kjær, P. F. (2018). The Status of Authority in the Globalizing Economy: Beyond the Public/Private Distinction. Indiana Journal of Global Legal Studies, 25(1), 3-11.

https://doi.org/10.2979/indjglolegstu.25.1.0003

Link to publication in CBS Research Portal

\section{General rights}

Copyright and moral rights for the publications made accessible in the public portal are retained by the authors and/or other copyright owners and it is a condition of accessing publications that users recognise and abide by the legal requirements associated with these rights.

Take down policy

If you believe that this document breaches copyright please contact us (research.lib@cbs.dk) providing details, and we will remove access to the work immediately and investigate your claim. 


\title{
The Status of Authority in the Globalizing Economy: Beyond the Public/Private Distinction
}

\section{Eva Hartmann and Poul F. Kjær}

\author{
Journal article (Accepted manuscript*)
}

\section{Please cite this article as:}

Hartmann, E., \& Kjær, P. F. (2018). The Status of Authority in the Globalizing Economy: Beyond the Public/Private Distinction. Indiana Journal of Global Legal Studies, 2811), 3-11. https://doi.org/10.2979/indjglolegstu.25.1.0003

This article was published as Hartmann, E., \& Kjær, P. F. (2018). The Status of Authority in the Globalizing Economy: Beyond the Public/Private Distinction. Indiana Journal of Global Legal Studies, 2811), 3-11. https://doi.org/10.2979/indjglolegstu.25.1.0003. No part of it may be reproduced, stored in a retrieval system, transmitted, or distributed in any form, by any means, electronic, mechanical, photographic, or otherwise, without the prior permission of Indiana University Press. For educational reuse, please contact the Copyright Clearance Center <http://www.copyright.com/>. For all other permissions, contact IU Press at <http://iupress.indiana.edu/rights/>.

* This version of the article has been accepted for publication and undergone full peer review but has not been through the copyediting, typesetting, pagination and proofreading process, which may lead to differences between this version and the publisher's final version AKA Version of Record. 


\title{
Final author's Version
}

The Status of Authority in the Globalizing Economy: Beyond the Public/Private

\author{
Distinction $^{1}$
}

\section{Eva Hartmann ${ }^{2}$ and Poul F. Kjaer ${ }^{3}$}

Indiana Journal of Global Legal Studies, 25, 1, 3 - 11 (Spring) 2018.

\section{Erosion of Public Authority}

Over the past decades, the perception has become dominate according to which national sovereignty and the authority of the state has been increasingly challenged or even substantially eroded. ${ }^{4}$ Economic globalization advancing a structural liberalist, i.e. neo-liberal dis-embedding of the economy is seen as the major reason for this erosion. Concerns have increased about the negative consequences for the social fabric of societies, deprived of the strong shock absorption capacity that the welfare states had established in the time of the embedded liberalism to use a term John Ruggie coined. ${ }^{5}$ The concerns have also helped nationalistic movements to gain in power in many high-income countries, not at least in the United States, calling for putting their economy first. Accordingly, a number of commentators have announced

${ }^{1}$ This article was developed with the support of the European Research Council within the project 'Institutional Transformation in European Political Economy - A SocioLegal Approach' (ITEPE-312331- www.itepe.eu).

${ }^{2}$ University of Cambridge. Email: ebh27@cam.ac.uk.

${ }^{3}$ Department of Management, Politics and Philosophy, Copenhagen Business School. Email: pfk.mpp@cbs.dk. Orcid: 0000-0002-8027-3601.

${ }^{4}$ E.g. David Held, Democracy and the Global Order. From THE MODERN STATE TO COSMOPOLITAN GOVERNANCE (Stanford University Press, Stanford, CA., 1995; JOSEPH CAMILLERI \& JIM FALK, THE END OF SOVEREIGNTY? THE POLITICS OF A SHRINKING AND FRAGMENTING WORLD (Edward Elgar Publishing, Cheltenham, 1992).

5 John Ruggie, Continuity and transformation in the world polity: Towards a Neorealist synthesis, 35, WORLD POLITICS, 261 (1983). 
a return of the nation state. ${ }^{6}$ In this special issue we will show that the retreat-of-the state thesis currently so dominant in public discourse overlooks important aspects of (legal) authority and its transformations since it conflates state and authority. This has major implications for not only the retreat-of-the-state thesis but also for the returnof-the-state thesis, as recently emerged. As reconstructed in the scene-setting followup piece to this brief introduction both theses underestimate important transformations of authority that have taken place.

With special issue we seek to contribute to a more nuanced analysis of the transformation of authority. The issue is the outcome of a conference that took place at the Copenhagen Business School in 2015, hosted by the research project 'Institutional Transformation in European Political Economy: A Socio-legal Approach' and funded by the European Research Council. ${ }^{7}$ The conference brought together scholars of law, political science as well as sociology, which made it possible to create interdisciplinary synergies. The dialogue is an important means to overcome the difficulties each discipline is confronted with when trying to account for the transformation of authority. It helps to disentangle authority and nation state, which all of the three disciplines, i.e. law, political science and sociology, tend to conflate. Law's own epistemology, for instance, grounds on an internal perspective, which hinders it to think through its categories, as legal scholars outline in this special issue. As a consequence, law tends to associate authority with public law, falling short of accounting for its transnationalization by other means than state-based international law. This lack of recognition has major epistemic consequences and requires political science and sociology to step in. However, these disciplines also need to come to terms with the methodological nationalism informing many of their theoretical notions. Part of this intellectual endeavor is the questioning of the distinction between public - private that often rather blurs than sharpens the analysis. Such a distinction cannot account for the public function of transnational private governance structure such as certifications, ratings or corporate social responsibility schemes of multinational companies. The study of the mechanisms by which private authority gains legitimacy is essential here. How have specific private modes of governance gained the standing as (de facto) public authority? How does public authority differ

\footnotetext{
${ }^{6}$ E.g. Mark Mazower, After the crisis, the nation state strikes back, FINANCIAL TIMES, NOVEMBER 26, 2014.

${ }^{7}$ For more information: www.itepe.eu.
} 
from and relate to private claims to authority within or in relation to processes of economic reproduction? Do private standards require less legitimacy because they have little enforcement capacity? Or is it rather the opposite? Do they need more legitimacy because they have not enforcement mechanism and depend on broad acceptance? These questions cannot be answered without studying the social praxis of establishing and exercising authority within firms, specific industrial sectors and different types of intermediary institutions such as (neo-)corporatist and governance institutions. ${ }^{8}$ The different contributions map the evolution of (legal) authority, emphasizing its dynamic, contested and contingent development. They explore the multiple sites where authority has been located and exercised at the local, national and transnational level and highlight the particular functional and normative features of public authority.

A historical perspective highlights that transnational private authority is not a recent phenomenon. The East-Indian company, for instance, had a number of public functions before the British government gained a more important role in organizing the British Empire, as Philipp Stern highlights in his study. ${ }^{9}$ However, we should refrain from understanding current change in terms of a comeback thesis, as Poul F. Kjaer outlines in the first contribution of this issue. Kjaer's analysis rejects the triplet narrative structure according to which a relative structural dominance of private authority prevailed pre-modern times and were substituted by the a relative dominance of nation state based public authority in the era of classical modernity from the American and French Revolutions onwards before returning in the contemporary era of global governance. Kjaer highlights that the relationship between public and private authority has evolved in a considerable more complex manner, unfolding quite differently at the local, national and transnational level of world society. His study reflects the changes in terms of changes of the sort of power which provides the foundation for authority and highlights that such power in fact is

${ }^{8}$ Poul F. Kjaer, From Corporatism to Governance: Dimensions of a Theory of Intermediary Institutions, 11 in THE EVOLUTION OF INTERMEDIARY INSTITUTIONS IN EUROPE: FROM CORPORATISM TO GOVERNANCE (Eva Hartmann \& Poul F. Kjaer eds. 2015).

${ }_{9}^{9}$ PHILIP J. STERN, THE COMPANY-STATE: CORPORATE SOVEREIGNTY \& THE EARLY MODERN FOUNDATIONS OF THE BRITISH EMPIRE IN INDIA (Oxford University Press, Oxford, 2011). 
reproduced in manner which cuts across the public/provide divide.

\section{Transnational Private Law}

Horatia Watt's account for an emerging informal, as she calls it, authority further concretizes the critique advanced by Kjaer of the triplet narrative. Her analysis studies transnational private authority through the lens of the methodology of transnational private law. Transnational private law emerged in its modern form in the liberal, pre-regulatory states of mid-nineteenth century Europe and has regained a fundamental role in the wake of the recent globalization wave. However, it is not a simple comeback, as Watt outlines, since the context has fundamentally changed and accordingly the function of this type of law. Nowadays private international law helps to mitigate the increasing collisions of jurisdiction and applicable law in an economically highly integrated world. Notably in the context of European integration it has become a crucial part of the specific inter-jurisdictional, regulatory-competitive arrangements. International private law does not replace the authority of the State but rather delineates whether a particular claim to govern is properly allocated to a State given the geographical location of the facts or the personal connections of the individuals or entities involved in question.

Claire Cutler zooms in further in her study of private transnational law in the field of investment and finance. She criticizes the prevailing assumption that private corporate actors are de jure insignificant as international subjects in contrast to states. This perspective obscures the de facto legal power of transnational corporations and other private corporate actors. Their power is much related to their authority in brokering disputes between public and public rights and interests. Cutler outlines how they are part of a "new constitutionalism" that re-orders domestic societies and political economies promulgating a system of law that aims to strengthen private property rights across different national jurisdictions. Her contribution focuses on investor-state regime and international finance regime with a view to illustrating the unfolding of private transnational governance and the legitimacy concerns involved. A core characteristic of this type of governance is increased flexibility required in an ever more crisis-prone transnational accumulation regime. The flipside of this flexibility is an increased fragmentation of law along sectoral lines setting limits to the enfolding of a transnational private authority. However, the fluidity of the hybrid 
arrangements with a constantly changing balance between public and private authority also creates room for resistance and contestations, Cutler concludes.

\section{Expertise and Private Authority}

The role of expertise in sustaining private authority is the focus of a number of contributions. Orr Karassin and Oren Perez highlight how private transnational regulations increasingly supplement public regulations in the field of environmental protection. They develop a five-category typology mapping the different ways in which public international and national law interact with private forms of environment regulations with 'incorporation', 'facilitation', 'abstention', 'substitution' and 'suppression' as core features. These categories shed light on the highly dynamic and interchangeable nature of public/private relations opening up opportunities in terms of access to information and expertise and increased adaptive capacity. The flipside, however, is an increased risk of regulatory capture, legitimacy problems and weak enforcement. These risks require meta-regulatory techniques by which public authorities can regain a certain control, the authors conclude.

In his contribution, Hans Krause Hansen turns to the global maritime industry and the emergence of the Maritime Anti-corporation Network, a private regime targeting corruption in the maritime business, its supply chains and in the context of interactions with public authorities around the world. Mirroring the findings of Karassin and Perez, Krause Hansen does not so much observe a fundamental shift between public and private authorities but rather a complementary relationship based on as a highly elaborated division of labor with private initiatives focusing on precrime prevention and public authorities on post-crime sanctioning. The involvement of the private regime can be understood as an attempt to make better use of private expertise about corruptions without which sanctions are difficult to carry out. However, as Kraus Hansen outlines, it also helps to extent public authority into the private sector making them reframing their business practices in terms of law and penal systems.

Oliver Kessler and Timo Walter focus on the relationship between expertise and authority in more theoretical terms. Their contribution develops a fundamental critique of the studies that transpose a Westphalian understanding of public authority to the transnational level by construing functional equivalents of public authorities. These studies fail to come to terms with the fundamental change in the nature of 
public authority since they do not question the presuppositions informing the notion of public authority. Kessler and Walter suggest a research agenda that pays attention to the epistemological relationship between authority and knowledge and the consequences of an increased entanglement of transnational fields of social practice and knowledge for the governance they instruct. The authors develop the concept of triple contingencies with a view to studying the complex interplay between common interests of powerful actors, the forms of scientific expertise and the forms of governance enacted through fields of organized social practices. With this perspective they develop another vantage point on what Cutler calls de facto legal power of corporate actors and highlight how the very notion of public authority is part of the triple contingencies. They use case of the European Union's newly launched Capital Union, i.e. harmonization of financial markets, as an illustration of how the intervention of and regulation by public authorities remain conditioned by an acceptance of the basic logic guiding financial markets and the sort of privately reproduced authority dominating the financial field. Public intervention is thus constrained by the expertise produced in the private sphere. As a consequence, the attempt to construe the relationship between public and private as a simple subordination of the private to the public is mistaken, the authors argue. Normative calls for supremacy of democracy and democratic decision making over privately constituted processes tend to depart from a highly simplified understanding of public/private relations. It requires a democratization of the knowledge production, which, however, is difficult for three important reasons as Kessler and Walter point out. The highly specialized nature of expertise is a natural disadvantage for nonexperts to make their voice heard. Another obstacle is the heterogeneity and polycentrism of regulatory expertise lacking a shared normativity. In the light of the absence of shared norms and values science and scientific knowledge becomes the main universalizing narrative, which again privileges expertocracy over democracy. Last but not least, the increasing commodification of science and expertise puts clear limits to the endeavor to democratize knowledge. It rather increases the gulf between the owners of expertise and the ones who have only the right to use it.

\section{Digitalization and Private Authority}

The commodification of knowledge is most explicit when it comes to digitalization. Chris Muellerleile and Susan Robertson draw on Max Weber's notion 
of authority and bureaucracy with a view to shedding light on the private authority of the digitally mediated world. Their study brings to the fore an important transformation of the more conventional state bureaucracy into a digitized transnational social order that provides new meaning to Weber's core notions efficiency, objectivity and rationality. The new order challenges the existing order by allowing for decentralization and flattening of a hierarchically organized bureaucracy and allowing for new ways of communication and community-building. However, the transformation also puts upset down the distinction between private and public. The Internet create new public spaces whose infrastructure is, however, fundamentally private, building on proprietary software produced in a highly concentrated market. But even the platforms themselves, hence the public space, are privately owned and traded on the stock market. Though their main market value is based on their capacity to attract a broad public and turning them into big data they can sell. The power of a digitally mediated social ordering thus depends on its capacity to make its private devices and infrastructure indispensable for the public and the community building.

Eva Hartmann explores another dimension of the private authority in terms of providing the knowledge the economy requires. This includes not only new information and communication technologies (ICT) but also the expertise to handle the technology. The study highlights how contested the claim to private authority can be by highlighting the competition between vendor-specific and vendor-independent ICT certification, each promoting a different type of handling the technology, which in turn reflects the interests of the different actors involved. This competition is part of a broader struggle over the ownership of the infrastructure allowing for this new type of social ordering, with proprietary software on one side and open-source software on the other side. The comparison points out different ways how the authority of these private certifiers depends on public authority. Vender-specific certifiers require public law that ensures the enforcement of their intellectual property rights. Accordingly their authority builds on the new constitutionalism that Cutler describes. In contrast, vendor-independent certifiers need public support to strengthen their organizational capacity to ensure the global reach of their authoritative standardsettings. The vendor-independent certifiers whose authority builds on their capacity to include a broad range of actors might provide the point of departure for an alternative to the new constitutionalism. 


\section{Private Authority and Responsibility}

The emerging transnational private authority raises the question of how responsibility is allocated. Fenner L. Stewart reviews critically the institutional design Corporate Social Responsibility (CSR) promotes as well as its claim to be able to serve collective welfare. The emphasis of CSR not only encourages corporations to assume the social responsibility, he argues. More importantly CSR increases the legitimacy for self-regulation of the business and makes governments depending on this collaboration. The profit imperative of business, however, undermines its capacity to assume the responsibility it claims. Stewart's study provides interesting insights into the role of theories, notably economic theories in providing the ground for this important shift of responsibility and hence the publicization of the private, as he also calls it. Stewart criticizes governance theory for deconstructing the publicprivate distinction without paying much attention to the consequences. In this sense his critique resonance with the triple contingencies analysis developed by Kessler and Walter that underlines the co-production of knowledge and governance.

Anna Leander highlights another dimension of the privatization of responsibility and shows how public law can enforce it. Her case study examines the impact of the legal arrangement of the Duty of Care (DoC) in the sphere of security and military matters. DoC is a tort law principle making care the duty of those providing a service or a good and has also major consequences for the way commercial security services are provided. Leander's analysis renders the public in the private visible. However, her study also outlines how public law helps to decenter, commercialize and de-politicize protection. Hence, her study questions the assumption according to which the increasing role commercial providers undermine the importance of public authority. On the contrary, public law can be an important enabler of private authority, Leander reminds us. However, public law has changed its character by portraying itself mainly as managerial, masking its deeply political nature.

\section{Tendencies of Re-politization}

De-politization is also at the core of Paddy Ireland's study of how the nature of corporate governance has changed since the nineteenth century. Ireland examines the changes in terms of corporate law and the rise of joint stock corporations and points out an important conceptual move. Corporations were initially understood as 
public institutions, which justified the privileges the legal status as joint stock corporations provided them. With the enactment of general incorporation status corporations became conceptualized as private enterprises allowing the businessmen to become the main beneficiaries of the privileges. This privatization of benefits stands in stark contrast to the increasing socialization of the production. With his study Ireland provides interesting insights into a mechanism that enables an increasing concentration of wealth that Thomas Pikkety's analysis prominently points out. ${ }^{10}$ One way of undermining this concentration process is to pay more attention to the public foundations of private power and reclaim an understanding of corporations as social institutions, Ireland concludes.

Matthias Goldmann goes a step further by developing a normative framework for evaluating the activities of institutional arrangements and bodies independently whether they are formally public or private. Drawing on discourse theory he develops a generic notion of publicness and public authority. He suggests that all institutional arrangements whose activities have consequences for human rights and democratic self-determination should qualify as public authorities. This suggestion has major normative implications for global arrangements, as Goldmann illustrates, using the sovereign debt restructuring as a case in point. Given its consequences for human rights and democratic self-determination the restructuring qualifies as public authority but has failed to far to account for its duties to ensure the respect of human rights and democratic self-determination, this contribution concludes.

\section{Conclusion}

This special issue contributes to a better understanding of the volatile and multifaceted evolution of the relationship between public and private authority in general and the important changes which the public-private divide has undergone over the last decades in particular. The contributions show that the publicness and authority of the nation states has always been one of several dimensions in a world characterized by local, national and transnational layers but also that recent and still ongoing transformations in the status of nation states implies a need to re-work the conceptual apparatus which studies of public as well as private authority relies on.

${ }^{10}$ THOMAS PIKETTY, CAPITAL IN THE TWENTY-FIRST CENTURY (Harvard University Press, Cambridge, MA. 2014). 